\title{
QUALITY OF LIFE OF PATIENTS WITH SARCOMA AFTER CONSERVATIVE SURGERY OR AMPUTATION OF LIMBS
}

\section{QUALIDADE DE VIDA DE PACIENTES COM SARCOMA APÓS CIRURGIA CONSERVADORA OU AMPUTAÇÃO DE MEMBROS}

\author{
Rogério Santos Silva ${ }^{1,2}$, Dirce Bellezi Guilhem ${ }^{1}$, Katia Torres Batista ${ }^{1,2}$, Lívia PenNa Tabet ${ }^{2}$ \\ 1. Universidade de Brasília UNB, Brasília, DF, Brazil. \\ 2. Rede Sarah De Hospitais De Reabilitação, Brasília, DF, Brazil.
}

\section{ABSTRACT}

Objective: To conduct an integrative review on quality of life (QOL) of patients with sarcoma who underwent conservative surgery or limb amputation. Methods: We conducted a six-step integrative review by searching the databases LILACS, SciELO, PePSIC, Embase, and PubMed, using the descriptors: "Quality of life", "Bone cancer", "Sarcoma", "Limb Salvage," and "Amputation." Ten studies were selected according to: database, type of study, methods, researcher's profession, sex, histological type, title, country/region, and periodical/year of publication. Results: Nine quantitative and one qualitative studies were included. All were conducted by physicians and correlated to QOL with the impact of diagnosis, psychosocial aspects, cancer treatment, and survival. Other aspects included type of surgery, functionality, rehabilitation, and a multidisciplinary approach. The QOL results were similar for conservative surgery and amputation in eight studies. In two, it was concluded that patients undergoing conservative surgery had a better QOL. Conclusion: The number of studies on QOL in patients with sarcoma is small. In most, there was no difference between the study groups. In addition, the studies indicated the importance of evaluation of QOL, since it has a direct effect on patients' physical manifestations and impacts their coping abilities. Level of evidence III, System review.

Keywords: Quality of life; Sarcoma; Limb Salvage; Amputation.

\section{RESUMO}

Objetivo: Conduzir uma revisão integrativa sobre qualidade de vida de pacientes com sarcoma, submetidos à cirurgia conservadora ou à amputação de membros. Métodos: Revisão integrativa em seis etapas, com busca nas bases de dados LILACS, SciELO, PePSIC, Embase e PubMed, utilizando-se os descritores: "qualidade de vida", "câncer ósseo", "sarcoma", "salvamento de membro" e "amputação". Dez estudos foram selecionados de acordo com banco de dados, tipo de estudo, método, profissão do pesquisador, sexo, tipo histológico, título, país/região, periódico/ano de publicação. Resultados: Foram incluídos nove estudos quantitativos e um qualitativo. Todos foram conduzidos por médicos e correlacionaram a qualidade de vida com impacto do diagnóstico, aspectos psicossociais, tratamento do câncer e sobrevida. Outros aspectos incluídos foram tipo de cirurgia, funcionalidade, reabilitação e abordagem multidisciplinar. Os resultados da qualidade de vida foram semelhantes para cirurgia conservadora e amputação em oito estudos. Em dois, concluiu-se que os pacientes submetidos à cirurgia conservadora tiveram melhor qualidade de vida. Conclusões: O número de estudos sobre qualidade de vida em pacientes com sarcoma foi pequeno. Na maioria, não houve diferença entre os grupos. Além disso, os estudos indicaram a necessidade de valorizar a avaliação da qualidade de vida, pois esta tem efeito direto nas manifestações físicas e impacto no enfrentamento da doença. Nível de evidência III, Revisão sistemática.

Descritores: Qualidade de vida. Sarcoma. Salvamento de membro. Amputação.

Citation: Silva RS, Guilhem DB, Batista KT, Tabet LP. Quality of life of patients with sarcoma after conservative surgery or amputation of limbs. Acta Ortop Bras. [online]. 2019;27(5):276-80. Available from URL: http://www.scielo.br/aob.

\section{INTRODUCTION}

Sarcomas are rare $(<1 \%$ of malignant neoplasms) and highly aggressive solid tumors. They affect all age groups, but their incidence is higher during childhood and adolescence. Further, they are the fifth leading cause of death due to cancer in children, adolescents, and young adults. They may occur at any anatomical location, but are more frequent in the extremities (60\%) and three times more frequent in the legs than in the arms. The most common histological types are osteosarcomas, Ewing's sarcomas, and chondrosarcomas, accounting for 95\% of all bone cancers. Lung metastases is frequently observed in the patients, particularly in those with Ewing's sarcomas (50\%) and osteosarcomas (90\%). ${ }^{1}$ The oncological treatment is multimodal, including surgery of the primary tumor with limb-sparing surgery or amputation of

All authors declare no potential conflict of interest related to this article.

Work conducted at the Sarah Network of Rehabilitation Hospitals. SMHS qd. 301, bl. A, Brasília, DF, Brazil. 70335-901

Correspondence: Rogério Santos Silva. CCSW1, Lote 2, Bloco B, Ed Mitre Moufarrege, Sudoeste, CEP 70680 - 165, Brasília, DF, Brazil. rogersasi@hotmail.com 
the affected limb, chemotherapy before surgery (neoadjuvant), chemotherapy after surgery (adjuvant), and radiotherapy for some histological types.

Cancer is a complex chronic disease, and its treatment requires an adequate infrastructure with material and human resources (a multi-professional team) and presents challenges to specialists and the society. The search for more effective and less mutilating treatments is necessary to cause minimal damage to the patient's quality of life (QOL) and functional abilities and to minimize psychological and emotional distress. Depending on the complexity of the case, in addition to the deterioration of QOL and psychological and emotional consequences, the patient may experience major physical and functional limitations. ${ }^{2}$

The concept of QOL has been studied in recent years through the integration of different areas of knowledge, such as medicine, social sciences, and psychology, and has been applied in a scientific and systematic manner since the 1970s. ${ }^{3}$ This concept has been systematized by the World Health Organization (WHO) and defined as physical, mental, and social well-being. It relates to the individual's perception about his/her health, personal satisfaction, correct diagnosis, adequate treatment, and cultural values. ${ }^{4}$ As a consequence of the change in paradigm for the understanding of health-disease process, from essentially biomedical to neglected socioeconomic, psychological, and social aspects, an interest in QOL as a global concept for health assessment has emerged. ${ }^{5}$ However, in some studies, the term "QOL" is still a synonym for physical health improvement. In literature, some studies have used this term considering only one of its dimensions, usually the physical dimension, without taking into account the psychological, environmental, and social dimensions. ${ }^{4}$

Currently, QOL in healthcare is very important, and WHO has developed instruments to assess QOL, within the multidimensional perspective, for several countries and cultures. The World Health Organization QOL Questionnaire (WHOQOL) ${ }^{6}$ instrument was initially created, and WHOQOLBREF followed, both of which have been validated for use in Brazil. ${ }^{7}$ Other specific instruments to access QOL that have been developed, such as the European Organization for Research and Treatment of Cancer Core QOL Questionnaire ${ }^{8}$ and the Functional Assessment of Cancer Therapy-General, ${ }^{9}$ were validated for use in Brazil, and they have been used in studies of patients with cancer.

The topic of QOL of patients with cancer has been frequently studied in the Brazilian and international literature. Therefore, the objective of the present study was to conduct a integrative review of the Brazilian and international literature on the QOL of patients with sarcoma who underwent limb-sparing surgery or amputation of upper or lower limbs.

\section{MATERIALS AND METHODS}

We did a integrative review to provides synthesis of knowledge and applicability of results of significant studies to practic. We did the six stages of the integrative review process by Ursi's data collect instrument: ${ }^{10} 1$ st phase - preparing the guiding question, 2 st phase - searching or sampling the literature, 3st phase - data collection, 4 st phase - critical analysis, 5 and 6 st phase - discussion of results and presentation. 1st phase: the guiding question was "Patients with sarcoma undergoing conservative limb surgery have better quality of life than those undergoing amputation?" 2st phase - searching or sampling the literature in this study, the following databases were searched to obtain the abstracts of interest: LILACS, SciELO, PePSIC, Embase, and PubMed. The following descriptors were used: "QOL," "Bone cancer," "Sarcoma," "Limb-sparing surgery," and "Amputation." 3st phase - data collection.
The criteria of inclusion of studies for the present review were the following: full-text studies that assessed the QOL of patients with sarcoma of the upper or lower limbs who underwent limb-sparing surgery or amputation to resect the primary tumor, written in Portuguese, English, or Spanish, with no publication date limit imposition. The data collection was performed between March and December of 2018. The search, assessment, and selection of studies and the extraction of results were conducted by two independent reviewers. The criteria for exclusion of studies were the following: studies that assessed the QOL of patients with different types of cancer or other diseases who underwent limb-sparing surgery or amputation, studies that compared the QOL of patients with bone cancer with that of the normal population, studies that assessed the QOL only in patients who underwent limb-sparing surgery or only in patients who underwent amputation, studies that focused only on functionality of the operated limb or survival of the patients, studies that emphasized on the type of endoprosthesis used in limb-sparing procedures, case studies of a single patient, studies that assessed the QOL of caregivers of patients with cancer, and studies of animals. Finally, the articles of thirty-two studies on the topic were obtained, and the five databases were examined to ensure there were no duplicates. Of these, ten studies were selected for this review. Figure 1 shows the flowchart of the data-search process. The analysis of the categories and subcategories of the abstracts was based on the study by Castro and Remor: ${ }^{11}$ database in which the article was indexed, Virtual Health Library, LILACS, SciELO, PePSIC, Embase, and PubMed; type of study, randomized clinical trial or observational study (cohort, case-control, cross-sectional, series, and case report); method used in the study, quantitative or qualitative; profession of the researcher who published the article

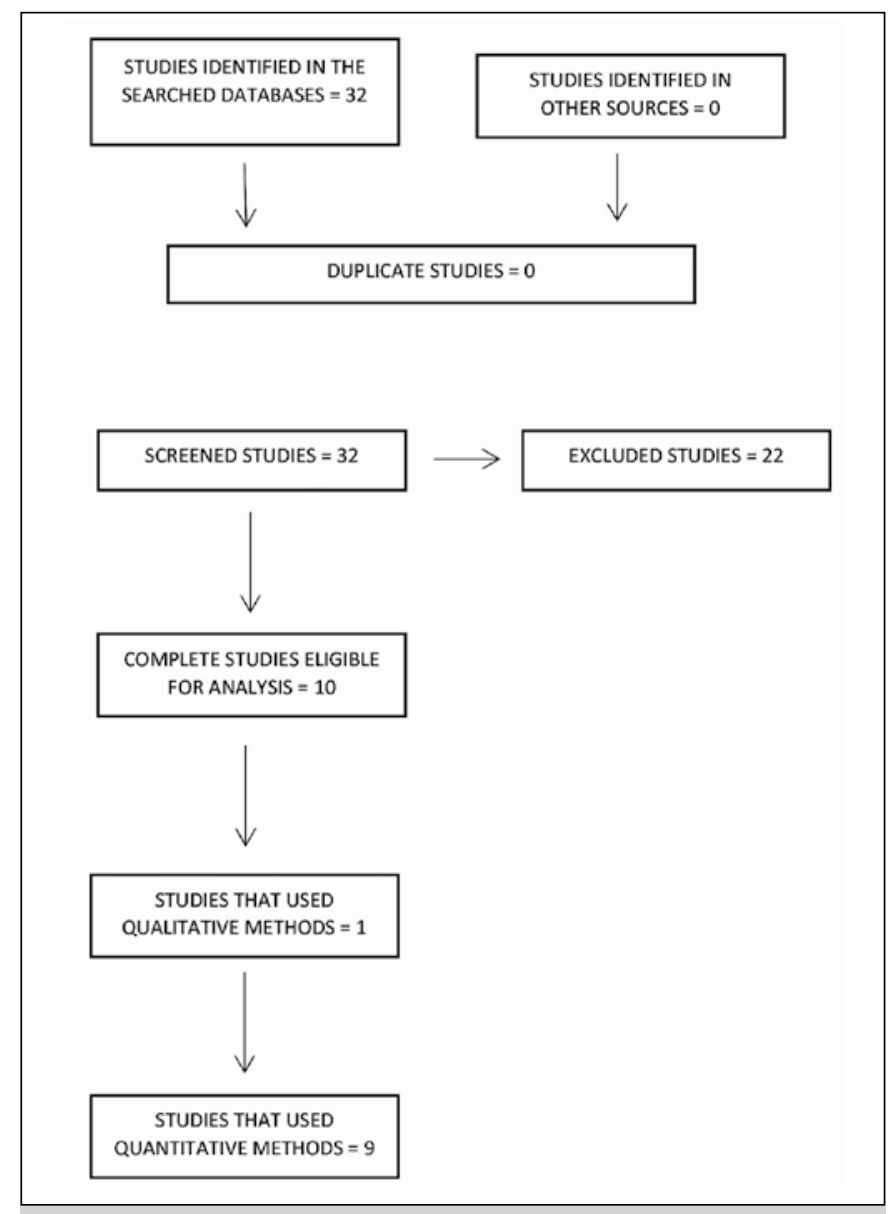

Figure 1. Flowchart of the data-search process. 
(physician, psychologist, nurse, physiotherapist, multidisciplinary team, or others); sex of the participants; histological type of the participants' sarcoma; title of the article (QOL, functionality, impact of the disease, type of treatment, rehabilitation, survival, surgical technique, and instruments were the terms used to collect the data); country and region where the research was conducted; and journal in which the article was published and year of publication. Ethical approval: This article does not contain studies with human or animal participants by any of the authors.

\section{RESULTS}

It is important to note that the number of scientific studies on the QOL of patients with sarcoma is small. Moreover, when we focused on the studies on the QOL of patients who underwent different types of surgery (limb-sparing or amputation), the number of studies decreased considerably, from thirty-two to ten. There were no duplicated studies in the five analyzed databases. All studies on the QOL of patients with sarcoma who underwent limb-sparing surgery or amputation were indexed in a single database (PubMed). With regard to the method, there was a predominance of quantitative studies (90\%) with one qualitative study (10\%).

The researchers responsible for the ten selected studies were all physicians (100\%) with the following specializations: oncology, hematology, and cancer surgery.

The majority of the studies (60\%) did not have data on the sex of the participants, and the male sex predominated in those that did (60\%). Further, $40 \%$ of the studies did not state the histological type of sarcoma, and in the remaining, there was a predominance of osteosarcoma (90\%), followed by Ewing's sarcoma (6\%) and chondrosarcoma (2\%). Other histological types mentioned were spindle-cell sarcoma, myxoid sarcoma, and leiomyosarcoma. It is important to note that in studies with information regarding the affected limbs, the lower limbs were more often affected (93\%) than the upper limbs (7\%). With respect to the type of surgical procedure performed to resect the tumor, the percentages of amputation and limb-sparing surgery were similar (approximately $50 \%$ each). All studies correlated QOL with several aspects of the disease. A majority correlated QOL with the impact of the diagnosis, psychosocial aspects, treatment of the cancer, and survival. Other aspects were also associated with the QOL of these patients, namely the type of surgery and surgical technique, functionality of the operated limb, postoperative rehabilitation, and multidisciplinary approaches. In the present review, the SF36 ${ }^{12}$ instrument was the most used (50\%) to assess the QOL, followed by the EORTC QLQC30.8 Moreover, $30 \%$ of the studies used the Beck Depression Inventory ${ }^{13}$ to evaluate depressive symptoms and other psychological disorders that could interfere with these patients' QOL. In addition to the illness itself, mood disorders in individuals with cancer have been receiving increasing attention. An association between cancer and mood disorders, such as depression, is frequent and may be related to poor adherence to treatment, progress, and QOL of patients. Another important concern among the researchers was to correlate postoperative functionality of the operated limb with QOL of patients who underwent the two types of surgery (limb-sparing surgery or amputation). The instrument of the American Musculoskeletal Tumor Society ${ }^{14}$ was the most frequently used (70\%) instrument among the studies, followed by other instruments, such as the Toronto Extremity Salvage Score ${ }^{15}$ and the Barthel Index for Activities of Daily Living ${ }^{16}$ to assess function. The country with the greatest number of publications was the United States, with $60 \%$ of the studies. These studies were conducted at the Sarcoma Center of the University of Texas MD Anderson Cancer Center in Houston, at the Ohio State University in Columbus, at the Mayo Clinic Schools of Medicine in Arizona and Florida, and at the Memorial Sloan-Kettering Cancer Center in New York City. The remaining studies were conducted in Japan, Germany, Sweden/ Norway, and Canada. It is important to note that we did not find any study conducted in Brazil on the researched topic that was eligible for inclusion in the present study.

There was a diversity of international journals that published on the topic. With regard to the year of publication, the articles for the ten studies were published between 1997 and 2013.

Finally, the results of QOL were similar among eight studies. However, in two studies, it was concluded that patients who underwent limb-sparing surgery had higher scores than those who underwent amputation. The conclusion of one qualitative study in our review was that the impact of surgical treatment on the QOL is based on the capacity to preserve anatomical structures necessary for function. With regard to functionality of the operated limb, three studies showed that patients who underwent limb-sparing surgery had higher scores than those who underwent amputation. Table 1 shows the studies included in the review according to author, journal, year, and country of publication, objective, methodology, and outcomes.

\section{DISCUSSION}

The critical analysis, discussion of results published on the QOL of patients with sarcoma who underwent limb-sparing surgery or amputation showed that the number of publications was small and that all considered QOL in its most encompassing context, including all domains as proposed and systematized by WHO. Although the concept of QOL used by WHO is encompassing, this view is not yet fully consolidated, which is demonstrated by the fact that most studies correlate QOL with treatment results, functionality of the operated limb, and survival of the patient.

The researchers investigated the physical, functional, and psychological aspects associated with the impact of the disease and with the surgical and oncological treatment. However, a large number of the excluded studies still used the concept of QOL, focusing only on physical well-being. ${ }^{4}$ There is a growing need to assess new procedures and medications for patients with bone cancers and at different stages of treatment. However, the attention of health professionals remains focused on the physical consequences of the disease and not on the QOL of the patient, taking into account the patient's subjective perception of his/her health. ${ }^{5}$

We emphasize on the fact that although the studies included in the present review address psychosocial aspects of QOL of patients with cancer, these studies were all conducted by physicians. The emotional challenges experienced by patients with cancer are many, including accepting the disease, dealing with visible body changes due to chemotherapy and surgery, dealing with changes to routines of daily life, and direct confrontation with death. For this reason, it is important that professionals from various areas of healthcare study this subject to provide integral care to patients and their families. ${ }^{27}$ According to Aksnes et al. ${ }^{22}$ in their study with 118 patients with osteosarcoma and Ewing's sarcoma, chronic pain in patients with amputated lower limbs is associated with poor walking functionality and deterioration of QOL. In addition, it may hinder the fitting of prosthesis and return to work and school and may cause emotional and sexual changes. The authors state that leg amputation below the knee results in significantly better functionality than amputation above the knee. Griesser et al. ${ }^{20}$ and Beck et al. ${ }^{23}$ observed that patients who underwent limb-sparing surgery or hip disarticulation had significantly reduced functional and QOL outcomes associated with urinary tract changes. Conversely, Yonemoto et al. ${ }^{18}$ reported that better postoperative functionality of the operated limb does not necessarily guarantee a better QOL of the patient. This study showed that patients who underwent limb-sparing surgery had higher QOL scores. 


\begin{tabular}{|c|c|c|c|c|}
\hline $\begin{array}{l}\text { Authors/ } \\
\text { journals }\end{array}$ & Country/year & Objective & Methodology & Outcomes \\
\hline Alan et al. ${ }^{17}$ & $\begin{array}{l}\text { USA } \\
1997\end{array}$ & $\begin{array}{l}\text { Assess the QOL of patients } \\
\text { who underwent limb-sparing } \\
\text { surgery or amputation of } \\
\text { lower or upper limb. }\end{array}$ & $\begin{array}{c}\text { Cross-sectional study } \\
\qquad \mathrm{N}=4 \\
\mathrm{QOL}=\text { Instruments to } \\
\text { measure psychosocial } \\
\text { function, economic } \\
\text { and overall well- } \\
\text { being, and Beck } \\
\text { Depression Inventory } \\
\end{array}$ & $\begin{array}{l}\text { The impact of treatment on QOL is based on the capacity to } \\
\text { preserve structures necessary for function to meet the patient's } \\
\text { expectations with appropriate oncologic treatments and on providing a } \\
\text { rehabilitation program that can be followed in the long-term to improve } \\
\text { functionality. The most used measures of QOL included measures } \\
\text { of physical, psychosocial, economic and overall well-being. }\end{array}$ \\
\hline Yonemoto et al. ${ }^{18}$ & $\begin{array}{l}\text { JAPAN } \\
2007\end{array}$ & $\begin{array}{l}\text { Assessment of the long-term } \\
\text { QOL of osteosarcoma survivors } \\
\text { who underwent amputation } \\
\text { or limb-sparing surgery. }\end{array}$ & $\begin{array}{l}\text { Prospective } \\
\text { Cohort Study } \\
\mathrm{N}=33 \\
\mathrm{QOL}=\mathrm{SF} 36\end{array}$ & $\begin{array}{l}\text { The group of patients who underwent limb-sparing surgery had } \\
\text { higher QOL scores than the group of amputation patients. There } \\
\text { were no differences in function between patients who underwent } \\
\text { amputation and those who did not. Side effects related to treatment, } \\
\text { such as secondary neoplasms and infertility, were rare. }\end{array}$ \\
\hline Ottaviani et al. ${ }^{19}$ & $\begin{array}{l}\text { USA } \\
2009\end{array}$ & $\begin{array}{l}\text { Assess the QOL of } \\
\text { osteosarcoma survivors } \\
\text { who underwent amputation } \\
\text { or limb-sparing surgery. }\end{array}$ & $\begin{array}{l}\text { Review study } \\
\mathrm{N}=\text { not reported } \\
\mathrm{QOL}=\mathrm{SF} 36 \text {, Beck } \\
\text { Depression Inventory }\end{array}$ & $\begin{array}{l}\text { QOL in terms of functionality, psychological success, and } \\
\text { effects on marriage and work did not differ significantly } \\
\text { between patients with osteosarcoma who underwent } \\
\text { amputation and those who did not. However, amputation } \\
\text { patients appear to have made satisfactory adjustments to their } \\
\text { deficits with or without a functional external prosthesis. }\end{array}$ \\
\hline Griesser et al..$^{20}$ & $\begin{array}{l}\text { USA } \\
2012\end{array}$ & $\begin{array}{l}\text { Assess the QOL of patients } \\
\text { who underwent hip amputation } \\
\text { or conservative surgery. }\end{array}$ & $\begin{array}{l}\text { Retrospective } \\
\text { cohort study } \\
N=15 \\
\text { QV }=\text { SF36 }\end{array}$ & $\begin{array}{l}\text { There was no statistical difference with regard to QOL and functionality } \\
\text { between the groups. The patients' age had an impact on physical } \\
\text { performance (the older the patient, the worse the physical performance). } \\
\text { Because of the small number of participants, it was not possible to } \\
\text { observe statistically significant differences between the two groups. }\end{array}$ \\
\hline $\begin{array}{l}\text { Zahlten- } \\
\text { Hinguranage } \\
\quad \text { et al. } .^{21}\end{array}$ & $\begin{array}{c}\text { GERMANY } \\
2004\end{array}$ & $\begin{array}{l}\text { Assess the QOL and } \\
\text { functionality of patients with } \\
\text { lower-limb sarcoma who } \\
\text { underwent amputation or } \\
\text { limb-sparing surgery. }\end{array}$ & $\begin{array}{l}\text { Retrospective } \\
\text { cohort study } \\
\mathrm{N}=124 \\
\text { QOL }=\text { EORTC } \\
\text { QLQC30 } \\
\end{array}$ & $\begin{array}{l}\text { The results of the assessments of QOL were similar in both } \\
\text { groups and the functionality scores were slightly higher } \\
\text { among the patients who underwent limb-sparing surgery. The } \\
\text { results showed that there is no advantage of limb-sparing } \\
\text { surgery over amputation with regard to overall QOL. }\end{array}$ \\
\hline Aksnes et al. ${ }^{22}$ & $\begin{array}{l}\text { SWEDEN and } \\
\text { NORWAY } \\
2008\end{array}$ & $\begin{array}{l}\text { Assessment of the long- } \\
\text { term QOL and functionality } \\
\text { of patients with sarcoma } \\
\text { who underwent limb-sparing } \\
\text { surgery or amputation. }\end{array}$ & $\begin{array}{l}\text { Prospective } \\
\text { cohort study } \\
\mathrm{N}=118 \\
\mathrm{QOL}=\mathrm{SF} 36\end{array}$ & $\begin{array}{l}\text { Patients who underwent amputation above the knee had lower } \\
\text { functionality scores than patients who underwent limb-sparing } \\
\text { surgery. There was no difference in QOL between patients who } \\
\text { underwent amputation and to limb-sparing surgery. It was concluded } \\
\text { that the majority of bone tumor survivors adapted to their physical } \\
\text { limitations, were able to work, and had a good overall QOL. }\end{array}$ \\
\hline Beck et al. ${ }^{23}$ & $\begin{array}{l}\text { USA } \\
2008\end{array}$ & $\begin{array}{l}\text { Assess functional ability } \\
\text { and QOL of patients with } \\
\text { sarcoma who underwent hip } \\
\text { amputation/disarticulation } \\
\text { or conservative surgery. }\end{array}$ & $\begin{array}{l}\text { Retrospective } \\
\text { cohort study } \\
\quad \mathrm{N}=97 \\
\text { QOL = EORTC } \\
\text { QLQC30 }\end{array}$ & $\begin{array}{l}\text { There was no difference in functionality between the two groups; } \\
\text { however, patients who underwent amputation/disarticulation had } \\
\text { more phantom pain and greater intestinal/bladder involvement. } \\
\text { There was no difference in QOL between the two groups. The } \\
\text { majority of the participants of both groups were fully independent with } \\
\text { regard to transportation, mobility, eating, and personal hygiene. }\end{array}$ \\
\hline Rougraff et a| $\left.\right|^{24}$ & $\begin{array}{l}\text { USA } \\
1994\end{array}$ & $\begin{array}{l}\text { Assessment of the long-term } \\
\text { functional ability and QOL of } \\
\text { patients with osteosarcoma } \\
\text { of the distal femur who } \\
\text { underwent limb-sparing } \\
\text { surgery or amputation. }\end{array}$ & $\begin{array}{c}\text { Prospective } \\
\text { cohort study } \\
N=127 \\
\text { QOL = Instruments to } \\
\text { measure psychosocial } \\
\text { function and Beck } \\
\text { Depression Inventory } \\
\end{array}$ & $\begin{array}{l}\text { There were no significant differences in survival rates or in the duration } \\
\text { of disease-free periods after surgery between the two groups. Patients } \\
\text { who underwent limb-sparing surgery had higher functionality scores than } \\
\text { those who underwent amputation. No difference was observed between } \\
\text { the groups with regard to the patient's acceptance of the postoperative } \\
\text { state, walking ability, or amount of pain. There was no apparent } \\
\text { difference in psychosocial or QOL outcomes between the groups. }\end{array}$ \\
\hline Gary et $\mathrm{al}^{25}$ & $\begin{array}{l}\text { USA } \\
2013\end{array}$ & $\begin{array}{l}\text { Assess the overall QOL of } \\
\text { lower-limb sarcoma survivors } \\
\text { who underwent amputation } \\
\text { or limb-sparing surgery. }\end{array}$ & $\begin{array}{c}\text { Original article } \\
\mathrm{N}=82 \\
\mathrm{QOL}=\mathrm{QOL} \\
\text { Questionnaire }(\mathrm{QLQ}), \\
\text { Minnesota Multiphasic } \\
\text { Personality Inventory, } \\
\text { and Visual Analog Scale }\end{array}$ & $\begin{array}{l}\text { The overall QOL of the patients who underwent limb-sparing surgery } \\
\text { was significantly better than that of patients who underwent amputation } \\
\text { ( } p<0.01) \text {. Significant differences were observed with regard to economic } \\
\text { well-being, professional satisfaction, and occupational relationships. }\end{array}$ \\
\hline Ronald et al. ${ }^{26}$ & $\begin{array}{c}\text { CANADA } \\
2009\end{array}$ & $\begin{array}{l}\text { Assess published studies } \\
\text { on QOL and functionality } \\
\text { of sarcoma survivors who } \\
\text { underwent limb-sparing } \\
\text { surgery or amputation. }\end{array}$ & $\begin{array}{l}\text { Review study } \\
\mathrm{N}=2710 \\
\mathrm{QOL}=\mathrm{SF} 36\end{array}$ & $\begin{array}{l}\text { Most studies showed that the functional outcomes were } \\
\text { better among patients who underwent limb-sparing surgery } \\
\text { than among those who underwent amputation. There } \\
\text { were no differences in QOL between the groups. }\end{array}$ \\
\hline
\end{tabular}

QOL : Quality of life. SF-36: Medical Outcomes Short-Form Health Survey. EORTC QLQC30: European Organization for Research and Treatment of Cancer. QLQ: Quality of life Questionnaire.

Rougraff et al. ${ }^{24}$ in a prospective cohort study with 227 patients with osteosarcoma of the distal femur who underwent limb-sparing surgery or amputation observed that the best QOL was related to the capacity of preserving anatomical structures necessary for functioning and meeting the patient's expectations regardless of the type of surgery. They also concluded that increased hospitalization and postoperative recovery time have a negative impact on the patient's QOL. Moreover, Gary et al., ${ }^{25}$ stated the importance of ensuring that the surgical procedure preserves anatomical structures required to sustain functioning and of undergoing a rehabilitation program with an interdisciplinary team. Zahlten-Hinguranage et al., ${ }^{21}$ in a retrospective cohort study with 124 patients who underwent limb-sparing surgery or amputation of lower limbs, obtained similar results for QOL in both groups and observed that the best QOL was associated with the maintenance of physical, cognitive, and sexual functioning; phantom pain control; body image acceptance; and a perception of overall quality of health. The same result for QOL was reported in the study by Ronald et al. ${ }^{26}$ 
Ottaviani et al. ${ }^{19}$ conducted a qualitative study of patients with osteosarcoma who underwent amputation and observed that the psychological and QOL outcomes were similar to those of patients who underwent limb-sparing surgery. The patients who underwent amputation had physical limitations related to the ability to walk, and most patients still experienced phantom pain. Some patients who underwent limb-sparing surgery required reoperation due to complications related to the endoprosthesis and infections, which are common in cancer patients. The QOL in terms of functionality of the operated limb, cognitive and psychosocial functioning, including marriage and work, did not differ significantly between patients with osteosarcoma who underwent amputation and those who did not. However, patients who underwent amputation appeared to have adapted to either using or not using prostheses.

In summary, it is important to conduct studies with teams of professionals from different areas, according to a trend of interdisciplinary follow-up of patients with cancer, arising from the fact that a single specialization cannot cover all the knowledge necessary to address a subject as complex as QOL of patients with cancer. We observed a global trend for a predominance in the quantitative approaches for the health of patients with chronic disease among studies on QOL in different types of cancer. ${ }^{28}$ However, the use of qualitative methods is important because it allows exploring specific features that involve various domains of the individual's everyday life. Moreover, Flek published studies on QOL, wherein psychometric instruments were used for its assessment. ${ }^{19}$ It has been reported that religion and spirituality have a positive influence on the capacity to cope with the disease and on QOL, ${ }^{28}$ but this was not observed in the studies selected for this review. Fleck at al ${ }^{29}$ proposed the challenge of "the key is not just to add years to life but to add life to years," to contribute to achieving the sought-after "humanization of healthcare," which includes a greater investment in QOL of patients with cancer. In recent years there has been an increasing interest in the development of instruments capable of assessing an individual's QOL in different situations.

\section{CONCLUSION}

The results of this review show that the QOL was not different between patients with sarcoma who underwent limb-sparing surgery and those who underwent amputation. A similar outcome was observed with regard to the functionality of the operated limb. The studies indicated the need to value the assessment of QOL in all its domains, including psychosocial and cultural aspects, because these may have a direct effect on physical manifestations and a positive impact on coping with the disease. Hence, they emphasize on the importance of support from a multidisciplinary team, of strong family relationships, of the possibility of returning to work, of professional performance, and of the ability to make plans and envision life prospects.

AUTHORS' CONTRIBUTIONS: Each individual author contributed individually and significantly to the development of this work. RSS (0000-0003-0937-2647)* Substantial contribution regarding conception and design of the study and acquisition, analysis, and interpretation of data; wrote and reviewed the article. DBG (00000003-4569-9081)*: reviewed the article and contributed to the intellectual concept of the study. KTB (0000-0003-1300-4281): analysis and interpretation of data; wrote and reviewed the article. LPT (0000-0001-9630-5738) analysis and interpretation of data; wrote and reviewed the article. *ORCID (Open Researcher and Contributor ID).

\section{REFERENCES}

1. Patel RS, Benjamin RS. Soft Tissue and Bone Sarcomas and Bone Metastases. In: Kasper D, Fauci A, Housr S, Longo D, Jameson JL, Loscalzo J, editors. Harrison's Principles of Internal Medicine, 19e. New York: McGraw-Hill Education; 2001. p. 625-7.

2. Malawaker MM, Sugarbaker PH. Musculoskeletal Cancer Surgery: Treatment of sarcomas and allied diseases. Washignton DC: Kluwer academic publishers; 2004

3. Castro M, Caiuby AVS, Draibe SA, Canziani MEF. Qualidade de vida de pacientes com insuficiência renal crônica em hemodiálise avaliada através do instrumento genérico SF-36. Rev Assoc Med Bras. 2003;49(3):245-9.

4. Da F, Bertan C, Castro EK. Qualidade de vida e câncer: revisão sistemática de artigos brasileiros. Psico. 2009;40(3):366-72.

5. Seidl EMF, Zannon CMLC. Qualidade de vida e saúde: aspectos conceituais e metodológicos. Cad Saúde Pública. 2004; 20(2):580-8.

6. The Whoqol Group. The World Health Organization QOL assessment (WHOQOL): Development and general psychometric properties. Soc Sci Med. 1998:46(12):1569-85.

7. Fleck MP, Louzada S, Xavier M, Chachamovich E, Vieira G, Santos L, et al. Aplicação da versão em português do instrumento abreviado de avaliação da qualidade de vida "WHOQOL-bref". Rev Saúde Pública. 2000;34(2):178-83.

8. Franceschini J, Jardim JR, Fernandes ALG, Jamnik S, Santoro IL. Reprodutibilidade da versão em português do Brasil do European Organization for Research and Treatment of Cancer Core QOL Questionnaire em conjunto com seu módulo específico para câncer de pulmão. J Bras Pneumol. 2010;36(5):595-602.

9. Pereira FMP, Santos CSVB. Estudo de adaptação cultural e validação da Functional Assessment of Cancer Therapy-General em cuidados paliativos. Rev Enf Ref. 2011;serllI(5):45-54.

10. Ursi ES. Prevenção de lesões de pele no perioperatório: revisão integrativa da literatura. [dissertação]. Ribeirão Preto: Universidade de São Paulo, Escola de Enfermagem de Ribeirão Preto. 2005. [Acesso em 21 out. 2018] Disponível em: http://www.scielo.br/pdf/rlae/v14n1/v14n1a17.pdf

11. Castro EK, Remor EA. Aspectos psicossociais e HIV/Aids: um estudo bibliométrico (1992-2002) comparativo dos artigos publicados entre Brasil e Espanha. Psicol Reflex Crít. 2004;17(2):243-50.

12. Campolina AG, Bortoluzzo AB, Ferraz MB, Ciconelli RM. Validação da versão brasileira do questionário genérico de qualidade de vida short-form 6 dimensions (SF-6D Brasil). Ciênc Saude Coletiva. 2011;16(7):3003-10.

13. Gandini RC, Martins MCF, Ribeiro MP, Santos DTG. Inventário de Depressão de Beck-BDI: validação fatorial para mulheres com câncer. Psico-USF. 2007;12(1):23-31.

14. Rebolledo DCS. Tradução e validação do instrumento Musculoskeletal Tumor Society Rating Scale (MSTS) para avaliação da função em pacientes com sarcomas ósseos dos membros inferiores [Internet]. São Paulo: Biblioteca Digital de Teses e Dissertações da Universidade de São Paulo. 2012. [Acesso em 21 out. 2018] Disponível em: http://www.teses.usp.br/teses/disponiveis/5/5140/tde-05042012-095050/.
15. Clayer M, Doyle S, Sangha N, Grimer R. The Toronto Extremity Salvage Score in Unoperated Controls: An Age, Gender, and Country Comparison. Sarcoma. 2012;2012:17213.

16. Minosso JSM, Amendola F, Alvarenga MRM, Oliveira MAC. Validação, no Brasil, do Índice de Barthel em idosos atendidos em ambulatórios. Acta Paul Enferm. 2010;23(2):218-23.

17. Alan W, Yasko AW, Reece GP, Gillis TA, Pollock RE. Limb-salvage strategies to optimize quality of life: the M.D. Anderson Cancer Center experience. CA Cancer J Clin. 1997;47(4):226-38.

18. Yonemoto T, Ishii T, Takeuchi Y, Kimura K, Hagiwara Y, Iwata S, et al. Evaluation of QOL (QOL) in long-term survivors of high-grade osteosarcoma: A Japanese single center experience. Anticancer Res. 2007;27(5B):3621-4.

19. Ottaviani J, Jaffe N. The Epidemiology of Osteosarcoma. In.: Jaffe N, Bruland OS, Bielack S. Pediatric and Adolescent Osteosarcoma. Cancer Treatment and Research. 2009;152:573-5. Ed. Springer.

20. Griesser MJ, Gillette B, Crist M, Pan X, Muscarella P, Scharschmidt T, et al Internal and External Hemipelvectomy or Flail Hip in Patients with Sarcomas. Am J Phys Med Rehabil. 2012;91(1):24-32.

21. Zahlten-Hinguranage A, Bernd L, Ewerbeck V, Sabo D. Equal QOL after limb-sparing or ablative surgery for lower extremity sarcomas. $\mathrm{Br} \mathrm{J}$ Cancer. 2004;91(6): 1012-4.

22. Aksnes LH, Bauer HCF, Jebsen NL, Folleras G, Allert C, Haugen GS, et al Limb-sparing surgery preserves more function than amputation: A Scandinavian Sarcoma Group Study Of 118 Patients. J Bone Jt Surg Br. 2008;90-B(6):786-94.

23. Beck LA, Einertson MJ, Winemiller MH, DePompolo RW, Hoppe KM, Sim FF. Functional outcomes and QOL after tumor-related hemipelvectomy. Phys Ther. 2008;88(8):916-27.

24. Rougraff B, Simon M, Kneisl J, Greenberg D, Mankin H. Limb Salvage Compared with Amputation for Osteosarcoma of the Distal End of the Femur. A Long-Term Oncological, Functional, and Quality-of-Life Study. The Journal of Bone and Joint Surgery-American Volume. 76(5):649-656, MAY 1994.

25. Gary E, Mason GE, Aung L, Gall S, Meyers PA, Butler R, Krüg S, et al. QOL Following Amputation or Limb Preservation in Patients with Lower Extremity Bone Sarcoma. Front Oncol. 2013;3:210.

26. Ronald D, Barr RD, Wunder JS. Bone and soft tissue sarcomas are often curable - But at what cost? A call to arms (and legs). Cancer. 2009;115(18):4046-54.

27. Staliano P, Araujo TCCFS. Estudos e pesquisas em Psico-Oncologia: levantamento realizado no Portal PePSIC. Revista da SBPH. 2009;12(2):54-68.

28. De Castro EK, Gross CQ. Salud y sociedad investigaciones en psicología de la salud y psicología social. Salud \& Sociedad. 2013;4(1):70-89.

29. Fleck MPA, Leal OF, Louzada S, Xavier M, Chachamovich E, Vieira G, et al. Desenvolvimento da versão em português do instrumento de avaliação de qualidade de vida da OMS (WHOQOL-100). Rev Bras Psiquiatr. 1999;21(1):19-28. 